\title{
Tidal exchange of water between a coastal marsh and the Río de la Plata estuary: the effect on the main physical and chemical variables
}

\author{
C. VILLAR ${ }^{1}$, L. de CABO \& C. BONETTO \\ "Instituto de Limnología "Dr. Raul A. Ringuelet" CC 712, 1900 La Plata, Buenos Aires, Argentina "Museo \\ Argentino de Ciencias Naturales "Bernardino Rivadavia", Av. A. Gallardo 470, 1405 Buenos Aires, \\ Argentina.
}

\begin{abstract}
At Punta Blanca, a Schoenoplectus californicus marsh of about $1,190 \mathrm{~m}$ long and $175 \mathrm{~m}$ wide is separated from the Río de la Plata estuary by a sand bar interrupted at one extreme by a channel through which tidal exchange of water occurs. Water movement in and out the marsh was estimated by installing a water stage height meter and following stage height variations through complete tidal cyclas. Incoming river water was sampled twice and outcoming marsh water three times along six tidal cycles, and main physical and chemical variables were determined. The marked decrease of the suspended matter concentration in the outcoming water, points out the large retention of sediments by the marsh. Oxygen concentration and water pH decreased in the outcoming water in four over six samplings. Higher concentrations of soluble reactive phosphorus in the outcoming tidal water suggest $P$ release related with riverine suspended matter transformation upon sedimentation, in response to acidification and reduction within the marsh environment. Nitrate impoverishment in the outeoming water suggests denitrification losses. Since ammonium concentration in the outcoming water was larger than in the incoming water, a net flux from the sediments is suggested. Nevertheless, as a result of nitrate depletion and ammonium release, a net loss of inorganic nitrogen took place.
\end{abstract}

Tey words: tidal marsh, nutrient exchange, Río de la Plata estuary,

Resumen: En Punta Blanca, un humedal de Schoenoplectus californicus de aproximadamente $1190 \mathrm{~m}$ de largo y $175 \mathrm{~m}$ de ancho se encuentra separado del estuario del Río de la Plata por una barra de arena interrumpida en un extremo por un canal a través del cual se produce un intercambio de agua durante cada ciclo de marea. Se estimó el intercambio de agua mediante la instalación de un hidrómetro, y el seguimiento de la variación de la altura del agua durante cada ciclo. Se tomaron dos muestras durante el ingreso y tres durante el egreso del agua del humedal en seis ciclos de marea, y se determinaron las principales variables físicas y químicas del agua. La marcada disminución de la concentración de sólidos suspendidos en el agua de egreso señala una significativa retención de sedimentos por el humedal. La concentración de oxígeno y el pH del agua disminuyó en el agua de salida en cuatro de seis muestreos. La mayor concentración de fósforo reactivo soluble en el agua que egresa del humedal sugiere la liberación de fósforo, la cual se relaciona con la transformación de los sólidos suspendidos aportados por el río luego de su sedimentación en el entorno ácido y reductor de los sedimentos del humedal. El empobrecimiento de la concentración de nitratos en el agua de egreso sugiere pérdidas por denitrificación. La mayor concentración de amonio en el agua de egreso sugiere liberación desde los sedimentos. Sin embargo, como resultado de la depleción de nitratos y la liberación de amonio, se observó una pérdida neta de nitrógeno inorgánico.

The hydrology, biogeochemistry and ecology of rivers is usually modified as a consequence of river-floodplain interactions. This fact has been increasingly recognised, specially for large rivers (Junk et al., 1989; Hamilton et al., 1997; Villar et al., 1998). Wetlands serve as sinks for nutrients to the extent that constructed wetlands are currently being employed to improve water quality (D'Angelo \& Reddy, 1994). Floodplain environments differ from most other aquatic habitats in that dramatic changes in water chemistry and biotic communities occur in response to periodic perturbations by the flood phase of the river. Sediment retention and transformation of solutes in floodplains can potentially modify the water quality of the river. River-floodplain interactions in the lower stretch of the Paraná River are responsible for major changes in water quality, both in the main course of the river and in its associated floodplain marshes (Bonetto et al., 1994; Villar et al., 1996, 1998). Because of tidal influence, a large but variable amount of water is daily exchanged between the estuary and the marshes, its magnitude depending on tidal amplitude and wind action. 
The aim of this paper is to improve our knowledge on the influence of coastal marshes of the right margin of the Río de la Plata estuary on the main physical and chemical variables of the coastal estuary water.

\section{MATERIAL AND METHODS}

\section{Study site}

A tidal marsh located at Punta Blanca on the right margin of the Río de la Plata estuary, roughly $70 \mathrm{~km}$ downstream Buenos Aires, was selected to study the nutrient exchange between the estuary and the marsh during tides (Fig. 1). The marsh is covered by a dense stand of emergent macrophytes, Schoenoplectus californicus being the dominant. The marsh is roughly $1,190 \mathrm{~m}$ long and $175 \mathrm{~m}$ wide, comprising an area of approximately $205,000 \mathrm{~m}^{2}$. Its mean water depth is $1 \mathrm{~m}$. The marsh is separated from the Río de la Plata estuary by a sand bar interrupted at one extreme by a channel roughly $20 \mathrm{~m}$ wide, through which the tidal exchange of water occurs. Mean tidal amplitude at P. Blanca is $0.6 \mathrm{~m}$ (SHN, 1996).

\section{Sampling and analytical procedures}

Six samplings were performed: July and November 1994, February, September and December 1995, and March 1996. Throughout each tidal cycle, 2 superficial water samples were

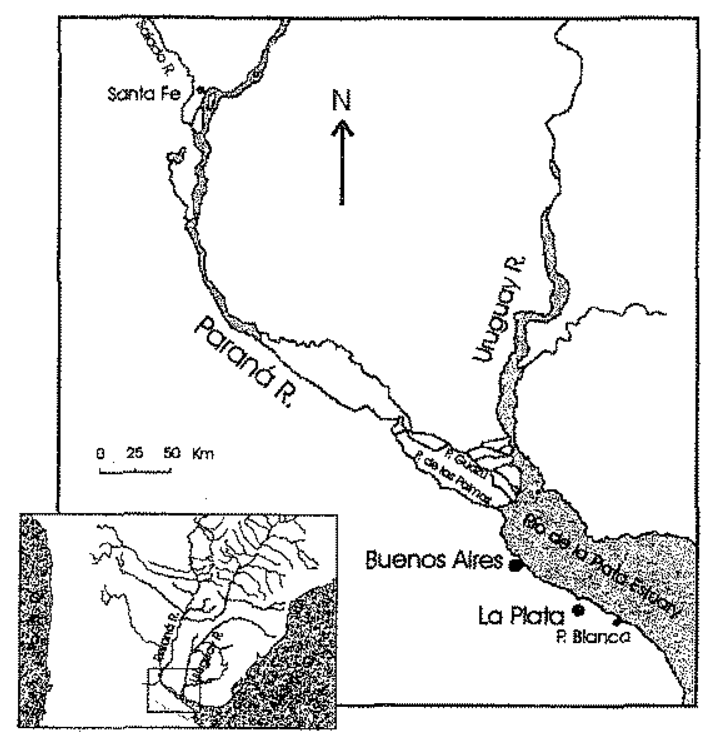

Fig. 1. Location of the sampling site at the Río de la Plata estuary. taken at the channel during the rising stage, and 3-4 along the receding stage. Water movement in and out the marsh was estimated by installing a water stage height meter and following stage height variations through the complete tidal cycle. The amount of water exchanged between the estuary and the marsh was estimated by means of the variation in water depth and the marsh surface. Net mass balance at the end of each tidal cycle was calculated multiplying the concentration of the element by the discharge at each sampling, and the summation of the products during the increasing water level minus the summation of the products during the decreasing phase.

Dissolved oxygen was determined with a YSI $51 \mathrm{~B}$ recorder and $\mathrm{pH}$, with an Orion $250 \mathrm{~A} \mathrm{pH}$ meter. Water samples were filtered through Whatman GF/C filters, and carried in ice to the laboratory. Dissolved nutrients were determined in the filtrate. Soluble reactive phosphorus (SRP) (molybdate-ascorbic) and nitrates plus nitrites (cadmium reduction followed by diazotation) were determined following Strickland \& Parsons (1972). Ammonium (indophenol blue) was measured according to Mackereth et al. (1978). Calcium (EDTA titration), bicarbonate (Gran titration) and sulphate (turbidimetry) were determined following APHA (1985). Suspended matter (SM) was determined as the dry weight difference after filtration through Whatman GF/ $\mathrm{C}$ filters. The filters were heated to $550^{\circ} \mathrm{C}$ for two hours previous to use.

\section{RESULTS}

Figure 2 shows the incoming estuary water composition followed by progressive changes in marsh outcoming water along the receding tidal phase, on six tidal cycles.

Temperature ranged $13-29^{\circ} \mathrm{C}$ in the incoming water and $16-32^{\circ} \mathrm{C}$ in the outcoming water. Dissolved oxygen concentrations decreased in the outcoming with respect to the incoming water in four over six samplings (Fig. 2). Mass balance of this element showed a consumption of 292-2,200 $\mathrm{mg} \mathrm{m} \mathrm{m}^{-2}$ cycle $^{-1}$ (Table 1). Depletion seemed to be related to water temperature, attaining $38-43 \%$ of the oxygen that entered the marsh in summer (Feb. 95 and Mar, 96). Water $\mathrm{pH}$ decreased in 4 over 6 samplings, without showing any discernible variation in the other two occasions. In summer, decrease ranged from 8.0-8.3 in the incoming water to $6.8-6.9$ in the outcoming water (Feb. 95-Mar. 96). SM concentration decreased in the outcoming water in all the samplings 
(Fig. 2). The incoming sediment retention, here referred as sedimentation rate (SR) ranged 2.4$119.0 \mathrm{~g} \mathrm{~m}^{-2} \mathrm{cycle}^{-1}$, being on average roughly $41 \%$ of the total SM that entered the marsh during the tidal cycle (Table 1). The highest SR was measured on Dec. 95, with a mean retention of $65 \%$ of the incoming suspended solids, in coincidence with the highest conductivity measured. Conductivity increased in the outcoming water in most samplings except in Dec. 95 when conductivity in the incoming water was an order of magnitude larger than in the other samplings, in coincidence with a prevailing south wind, bringing more saline water from the outer estuary (Table 1). Such events occur several times per year.

Nitrate decreased in 5 of 6 samplings, being depletion larger in summer (Fig. 2). Observed depletion ranged $4-134 \mathrm{mg} \mathrm{m}^{-2}$ cycle $^{-1}$ (Table 1). Roughly 92 and $37 \%$ of the nitrate that entered the marsh on Feb. 95 and Mar. 96 was depleted. Although ammonium decreased in 3 samplings, large increments were attained in the outcoming marsh water during summer $(150,269$ and $550 \%$ increase in Feb. 95, Dec. 95 and Mar. 96, respectively) (Fig. 2, Table 1). The combined effect of the ammonia and nitrate opposite trends was a net loss of inorganic N: on Feb. 95 and Mar. 96 nitrate attained a depletion of 94 and $134 \mathrm{mg} \mathrm{N} \mathrm{m}^{-2}$ cycle $^{-1}$, respectively, while ammonium produced an increase of 28 and 55 $\mathrm{mg} \mathrm{N} \mathrm{m}{ }^{-2}$ cycle ${ }^{-1}$, respectively, resulting in a net loss of 66 and $79 \mathrm{mg} \mathrm{N} \mathrm{m}^{-2}$ cycle $^{-1}$.

SRP increased in the outcoming water in 4 over 6 samplings and decreased in the other two (Figure 2, Table 1). Bicarbonate and calcium concentrations increased in the outcoming water in all the samplings (except calcium on Set. 95). Sulphate did not show any discernible pattern.

\section{DISCUSSION}

The observed trend to decrease $\mathrm{pH}$, dissolved oxygen, inorganic nitrogen and SM, and to increase SRP, bicarbonate and calcium concentrations in the outcoming marsh water with respect to the incoming water during tidal cycles suggests the large influence of river water exchange with coastal environments on water quality.

The SM decrease in the outcoming marsh water points out the large sediment retention within the floodplain environment. Decreased water velocity, associated with the trapping effect of the marsh vegetation are possible causes for the observed results (Depetris \& Kempe, 1990). The sediment load of the Lower Parana is mainly contributed by the Bermejo River (Pedrozoet al., 1987). Its water is saturated with calcium carbonate (Pedrozo \& Bonetto, 1987), and its SM contains calcium carbonates. Emergent macrophyte biomass within the marsh is large, attaining $1,450 \pm 264 \mathrm{~g} \mathrm{~m}^{-2}$ (Villar, 1997). Most of the produced biomass fell down during winter and undergoes decomposition in the sediment surface enhancing the oxygen consumption and the acidification of the marsh water (Bonetto, 1996). The observed pattern in dissolved gas concentrations indicates the strong influence of heterotrophic mechanisms below the water surface. The observed release of calcium, bicarbonate and SRP concentration in the outcoming marsh water suggests partial dissolution of the riverine SM upon deposition within the acid sediment-water interface of the marsh. Consistently, higher levels of SRP concentrations in floodplain water than in the Paraná River in response to river SM transformation in the anoxic and acid marsh environment were reported (Villar et al., 1998).

Table 1. Temperature $\left({ }^{\circ} \mathrm{C}\right)$, conductivity $\left(\mu \mathrm{S} \mathrm{m}^{-1}\right)$, exchanged water volume $\left(\mathrm{m}^{3}\right)$, and mass balance (g and $\mathrm{mg} \mathrm{m}^{-2}$; release, $\downarrow$ retention) of the main physical and chemical variables measured during each tidal cycle at the P. Blanca tidal marsh.

\begin{tabular}{|c|c|c|c|c|c|c|c|c|c|c|}
\hline Date & $\begin{array}{l}\mathrm{T} \\
{ }^{\circ} \mathrm{C}\end{array}$ & $\begin{array}{l}\text { Cond. } \\
\mu S \mathrm{~cm}^{-1}\end{array}$ & $\begin{array}{c}\text { Exch. vol, } \\
\mathrm{m}^{3}\end{array}$ & $\begin{array}{c}\mathrm{O}_{2} \\
\mathrm{mg} \mathrm{m}^{-2}\end{array}$ & $\begin{array}{l}\mathrm{SM} \\
\mathrm{g} \mathrm{m}^{-2}\end{array}$ & $\begin{array}{l}\mathrm{N}-\mathrm{NH}_{4}{ }^{+} \\
\mathrm{mg} \mathrm{m}^{-2}\end{array}$ & $\begin{array}{l}\mathrm{N}-\mathrm{NO}_{3} \\
\mathrm{mg} \mathrm{m}^{-2}\end{array}$ & $\begin{array}{c}\mathrm{SRP} \\
\mathrm{mg} \mathrm{m}^{-2}\end{array}$ & $\begin{array}{c}\mathrm{Ca}^{2+} \\
\mathrm{mg} \mathrm{m}^{-2}\end{array}$ & $\begin{array}{l}\mathrm{HCO}_{3} \\
\mathrm{mg} \mathrm{m}^{-2}\end{array}$ \\
\hline Jul.94 & 14 & 703 & 51,450 & 0 & 2.4 & $\downarrow 13.6$ & $\downarrow 58$ & $\downarrow \quad 9.3$ & $\uparrow 802$ & $\uparrow 2,420$ \\
\hline Nov.94 & 22 & 459 & 109,000 & 0 & $\downarrow 11.8$ & $\downarrow 11.5$ & $\downarrow 18$ & $\uparrow 106.6$ & 763 & 8,300 \\
\hline Feb.95 & 28 & 296 & 26,754 & 408 & 5.8 & $\uparrow 27.7$ & $\downarrow 94$ & $\hat{i} 10.7$ & $\uparrow 437$ & 4,620 \\
\hline Sep.95 & 22 & 327 & 45,276 & 292 & 6.5 & 0.4 & - & 2.4 & 0 & 1,460 \\
\hline Dec.95 & 24 & 5,100 & 94,668 & 777 & $\downarrow 119$ & $\uparrow 54.6$ & $\downarrow \quad 4$ & $\downarrow 10.6$ & $\uparrow 1460$ & 2,900 \\
\hline Mar.96 & 29 & 606 & 109,074 & $\downarrow 2,200$ & $\downarrow 20.6$ & $\uparrow 55.0$ & $\downarrow 134$ & $\uparrow 2.9$ & $\uparrow 447$ & $\uparrow 2,380$ \\
\hline
\end{tabular}




\section{Dissolved oxygen $\left(\mathrm{mg} \mathrm{r}^{-1}\right)$}
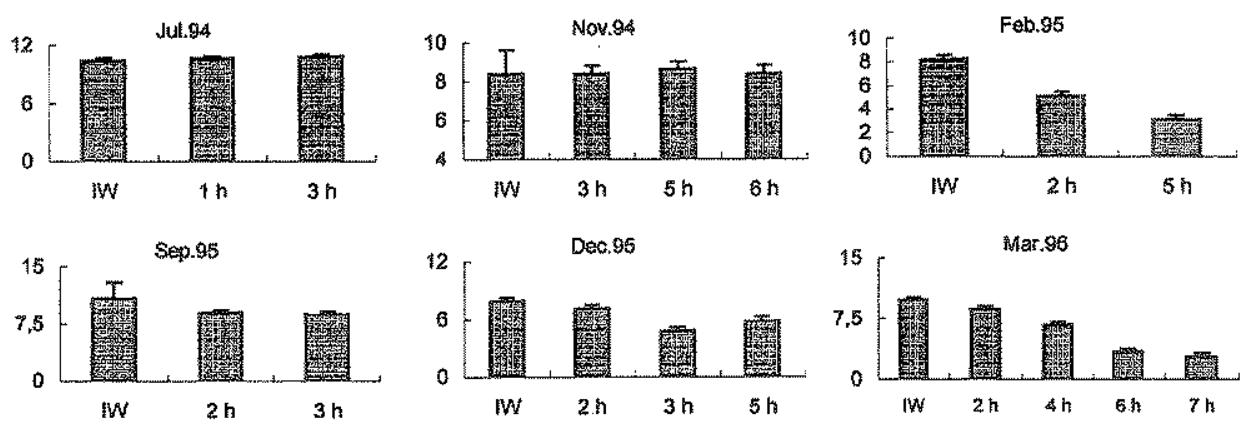

$\mathrm{pH}$
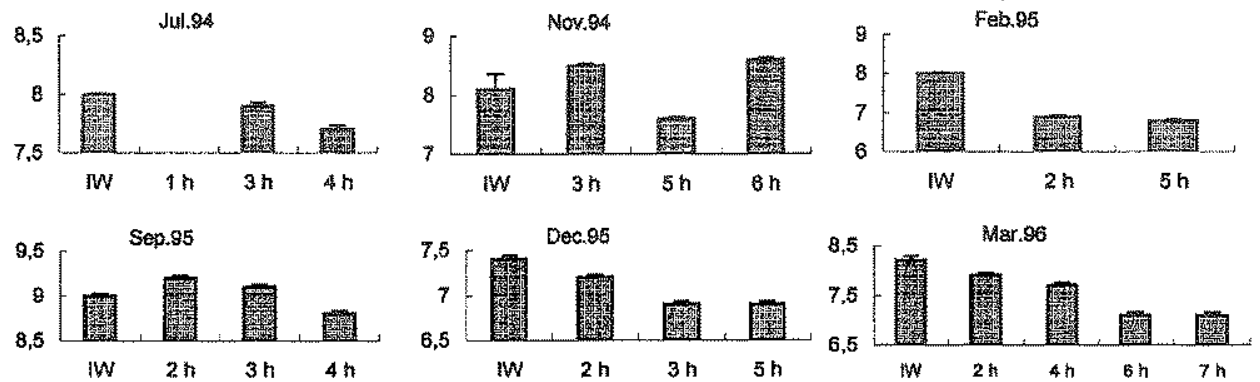

Suspended matter $\left(\mathrm{mg} \mathrm{l}^{-1}\right)$
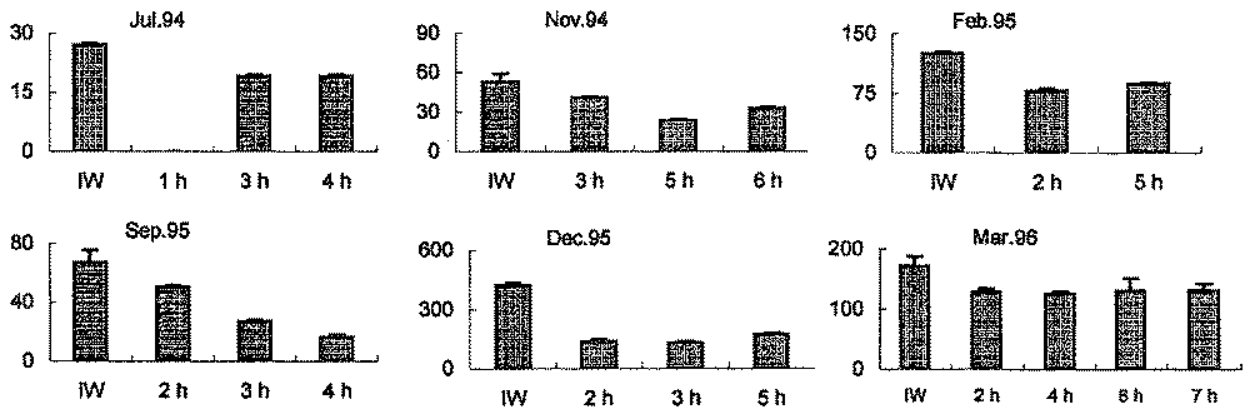

$\operatorname{SRP}\left(\left.\mu g\right|^{-1}\right)$
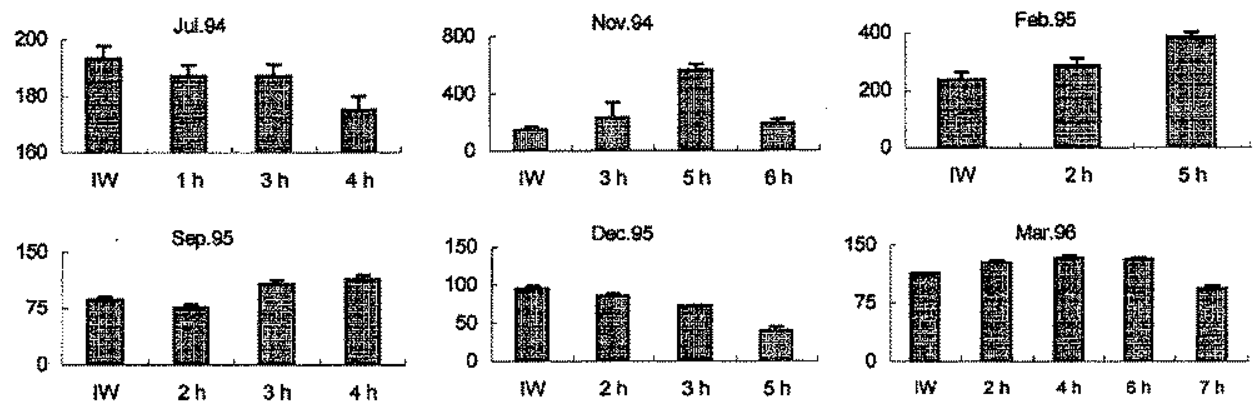

Fig. 2. Measured limnological variables in the incoming estuary water (IW, mean of two samplings), and successive samplings at different times (in hours) in the outcoming water at Punta Blanca tidal marsh. Mean \pm standard error. 
$\mathrm{N}-\mathrm{NO}_{3}^{-}\left(\mathrm{Mg}^{-1}\right)$
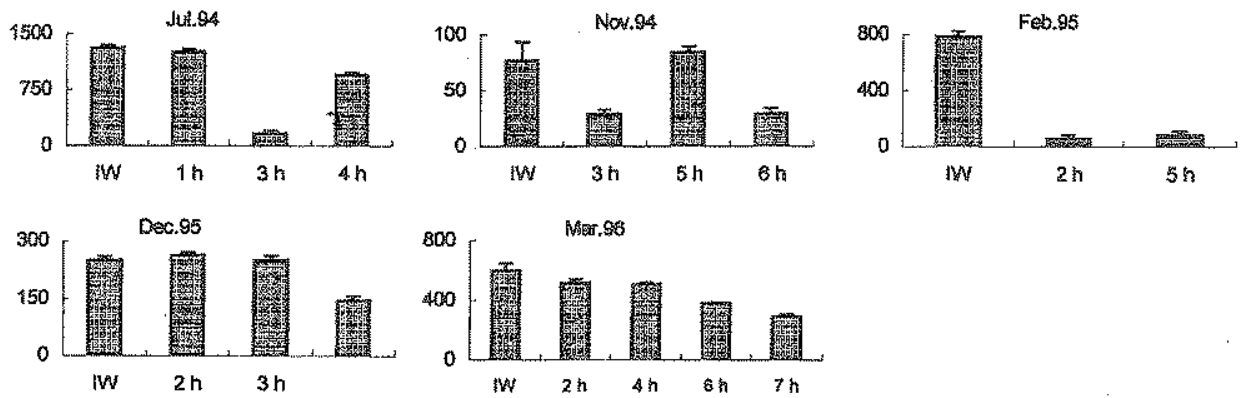

\section{$\mathrm{N}_{\mathrm{NH}} \mathrm{NH}^{+}\left(\mu \mathrm{g}^{-1}\right)$}
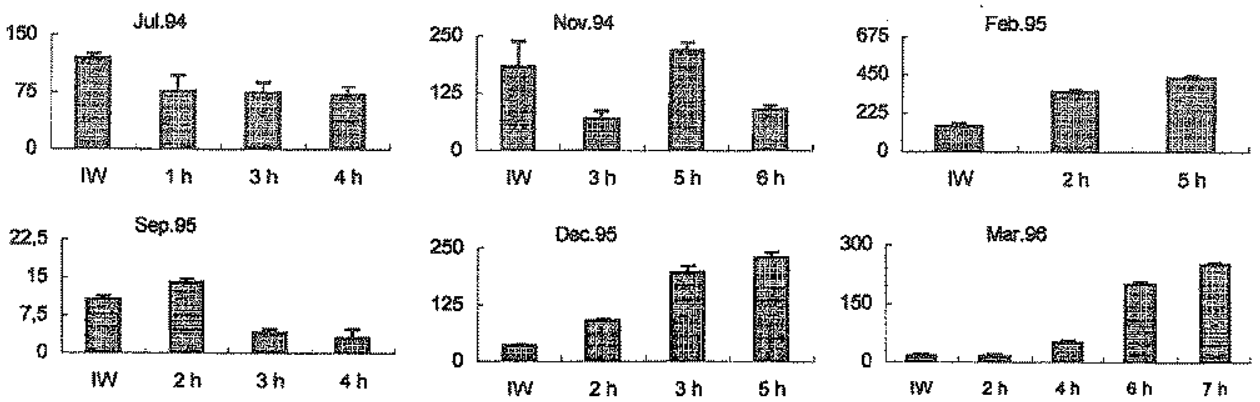

$\mathrm{Ca}^{2+}\left(\mathrm{mg} \mathrm{^{-1 }}\right)$
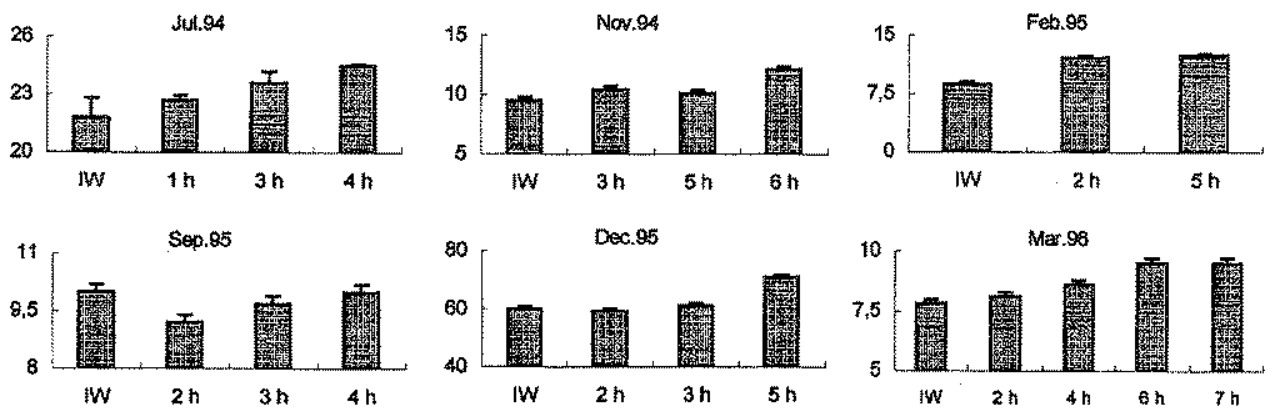

$\mathrm{HCO}_{3}^{-}\left(\mathrm{mg} \mathrm{l}^{-1}\right)$
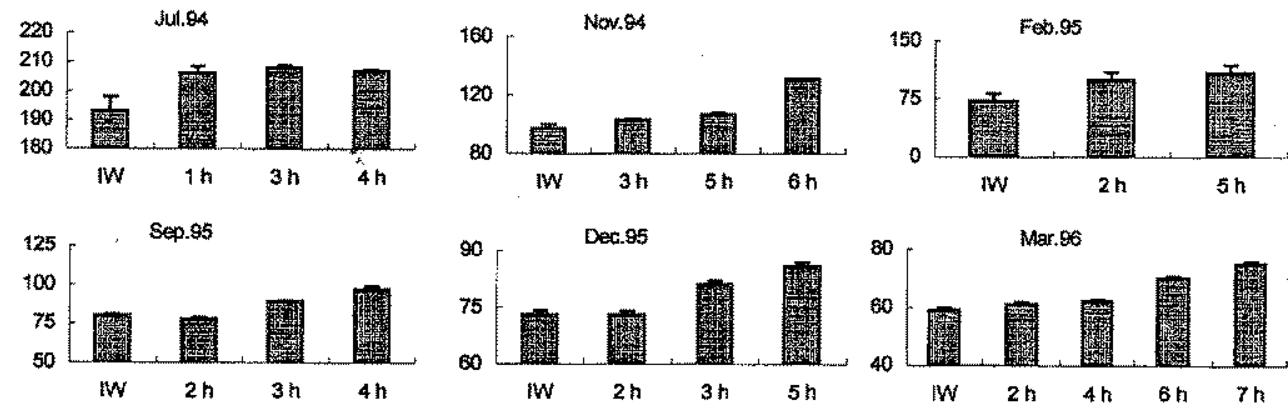

Fig. 2. Measured limnological variables, continued. 
The observed nitrate decrease in the outcoming marsh water suggests that coastal marshes are important sinks of inorganic nitrogen (Villar et al., 1997, 1998). The main pathways for nitrate removal at the soil-water interface of floodplains include biological assimilation, dissimilatory nitrate reduction to ammonium, and denitrification (D'Angelo \& Reddy, 1993). Under conditions of anaerobic organic sediments in contact with a water layer, there is a large demand for nitrate to be used as electron acceptors. Ammonium inputs may also be lost through coupled nitrificationdenitrification (Reddy et al., 1989). Large increases in marsh ammonium concentrations over the incoming water were observed in $50 \%$ of the samplings, suggesting a large ammonium flux from the sediments to the overlaying water column. Low nitrate depletion together with high release of ammonium in the outcoming water was observed in coincidence with the highest conductivity measured (Dec. 95). Ammonium constitutes a substantial portion of the sedimentwater flux of $\mathrm{N}$ in estuaries and coastal marine systems (Gardneret al., 1991). In sediments with oxidised surface layers, the percentage of mineralised nitrogen that is nitrified-denitrified, compared with that released directly as ammonium, seems to be related with the presence of higher salt content. In estuarine systems, a significant portion of the $\mathrm{N}$ is released as ammonium. Gardner et al. (1991) suggest that whereas adsorption on cation exchange sites (e.g. clay particles and associated humic substances) hinder the mobility of ammonium in sediments, the presence of sea salts could partially neutralise the polarity of ammonium ion (by ion pair formation) and also cause the cation exchange sites in the sediments to be mostly occupied by cations.

\section{BIBLIOGRAPHY}

APHA. 1985. Standard Methods for the examination of water and wastewater. Amer. Publ. Health Assoc., Washington, $1268 \mathrm{pp}$.

Bonetto, C. 1996. River-floodplain interactions in the Lower Paraná River. IFS Research Grant A/1711$2 \mathrm{~F}$. Final report.

Bonetto, C., L. de Cabo, N. Gabellone, A. Vinocur, J. Donadelli \& F. Unrein. 1994. Nutrient dynamics in the deltaic floodplain of the Lower Parana River. Arch. Hydrobiol. 131: 277"295.

D'Angelo, E. M. \& K. R. Reddy. 1993. Ammonium Oxidation and Nitrate Reduction in Sediments of a
Hypereutrophic Lake. Soil Science Society of America Journal. 57(4): 1156-1163.

- 1994. Diagenesis of organic matter in a wetland receiving hypereutrophic Lake Water: II. Role of inorganic electron acceptors in nutrient release. $J$. Environ. Qual. 23: 937-943.

Depetris, P. \& S. Kempe. 1990. The impact of the El Niño 1982 event on the Paraná River, its discharge and carbon transport. Palaeogeography, Palaeoclimatology, Palaeoecology (Global and Planetary Change Section) 89: 239-244.

Gardner, W. S., S. P. Seitzinger \& J. M. Malczyk. 1991. The effects of sea salts on the forms of nitrogen released from estuarine and freshwater sediments: does ion pairing affect ammonium flux? Estuaries 14(2):157-166.

Hamilton, S. K., S. J. Sippel, D. F. Calheiros \& J. M. Melack. 1997. An anoxic event and other biogeochemical effects of the Pantanal wetland on the Paraguay River. Limnol. Oceanogr. 42(2): 257. 272.

Junk, W. J., P. B. Bayley \& R. E. Sparks. 1989. The flood pulse concept in river-floodplain systems. In D.P. Dodge (ed) Proceedings of the International Large River Symposium. Can. Spec.Publ. Fish. Aquat. Sci. 106: $110-127 \mathrm{pp}$.

Mackereth, F., J. Heron \& J. Talling. 1978. Water analysis: some revised methods for limnologists. Freshwater Biol. Assoc. Cd., Pub. No36.

Pedrozo, F. \& C. Bonetto.1987. Nitrogen and phosphorus transport in the Bermejo River (South America). Rev. Hydrobiol. Trop. 20(2): 91-99.

Reddy, K. R., W. Patrick \& C. Lindau. 1989. Nitrification-denitrification at the plant root. sediment interface in wetlands. Limnol. Oceanogr. 34: 1004-1013.

SHN. 1996. Tablas de marea. Separata zona Río de la Plata. Servicio de Hidrografía Naval, Buenos Aires.

Strickland, J. \& T. Parsons. 1972. A practical Handbook for seawater analysis. Bull. Fish. Res. Bd. Canada, $233 \mathrm{pp}$.

Villar, C. A., 1997. Interacción rio-valle aluvial. Intercambio de nutrientes y contaminantes. Tesis Doctoral. Univervidad de Buenos Aires, 182pp.

Villar, C. A., L. de Cabo \& C. Bonetto. 1996. Macrophytic primary production and nutrient concentrations in a deltaic floodplain marsh of the Lower Paraná River. Hydrobiologia 330: 59-66.

Villar, C. A, L. de Cabo, P. Vaithiyanathan \& C. Bonetto. 1997. Litter decomposition of emergent macrophytes in littoral environments of the Río de la Plata basin. $7^{\circ}$ Conferencia Internacional sobre conservación y gestión de lagos. $L A C A R$ 97. Vol.1: 276-279.

- 1998. River - floodplain interactions: nutrient concentrations in the Lower Paraná River. Arch. Hydrobiol. 142(4): 433-450. 